\title{
Focused molding using adhesive pads in Mehta casting for early-onset scoliosis
}

\author{
Roby Abraham ${ }^{1 *}$, Paul Sponseller ${ }^{2}$ \\ From 11th International Conference on Conservative Management of Spinal Deformities - SOSORT 2014 \\ Annual Meeting \\ Wiesbaden, Germany. 8-10 May 2014
}

\section{Background}

Early-onset scoliosis is often effectively managed by serial casting. Properly localizing the apex of the molds with the cast in place is challenging. The authors explored the effectiveness of a novel technique: incorporation of adhesive pads placed over the major curve apex before Mehta casting.

\section{Aim}

To determine the effect of adhesive pads placed over the apex of scoliosis curves on curve correction 1) after the first cast and 2) after final cast.

\section{Study design}

Case series.

\section{Method}

The 27 patients who received body casts (2000 through 2013) were divided into 2 groups, those without and with apical adhesive pads ( 5 to 6 layers of pads placed on the major curve's apex during casting): non-pad (NP) group $(n=12)$ and pad $(P)$ group $(n=15)$, respectively. Groups were compared for percentage of Cobb angle change from the first cast and curve correction to a Cobb angle of less than $25^{\circ}$ with Student $t$ and chisquare tests (significance, p value less than .05).

\section{Results}

The mean percentage of major first-cast curve correction was $39 \% \pm 18 \%$ and $56 \% \pm 17 \%$ in the NP and $\mathrm{P}$ groups, respectively. Of the 26 patients out of cast, 11 (42\%) had a Cobb angle of less than $25^{\circ}: 3$ (25\%) and 8 (57\%) in the NP and P groups, respectively. The mean differences between the 2 groups in percentage of major

${ }^{1}$ SUNY Downstate Medical Center, Brooklyn, NY, USA

Full list of author information is available at the end of the article curve correction and this Cobb angle correction were significant: $\mathrm{p}=0.023$ and 0.005 , respectively.

\section{Conclusion}

Adhesive pads placed over major curve(s) during Mehta casting were effective in increasing the amount of major curve correction from the first cast for idiopathic earlyonset scoliosis, and in decreasing curves to less than $25^{\circ}$ at final follow up.

\section{Level of evidence}

Level III; Retrospective comparative study.

\section{Authors' details}

${ }^{1}$ SUNY Downstate Medical Center, Brooklyn, NY, USA. ${ }^{2}$ The Johns Hopkins University, Baltimore, MD, USA.

\section{Published: 4 December 2014}

\section{doi:10.1186/1748-7161-9-S1-O36}

Cite this article as: Abraham and Sponseller: Focused molding using adhesive pads in Mehta casting for early-onset scoliosis. Scoliosis 20149 (Suppl 1):O36.

Submit your next manuscript to BioMed Central and take full advantage of:

- Convenient online submission

- Thorough peer review

- No space constraints or color figure charges

- Immediate publication on acceptance

- Inclusion in PubMed, CAS, Scopus and Google Scholar

- Research which is freely available for redistribution 